\title{
Between a Rock and a Hard Drive
}

\author{
Kristin Lucas
}

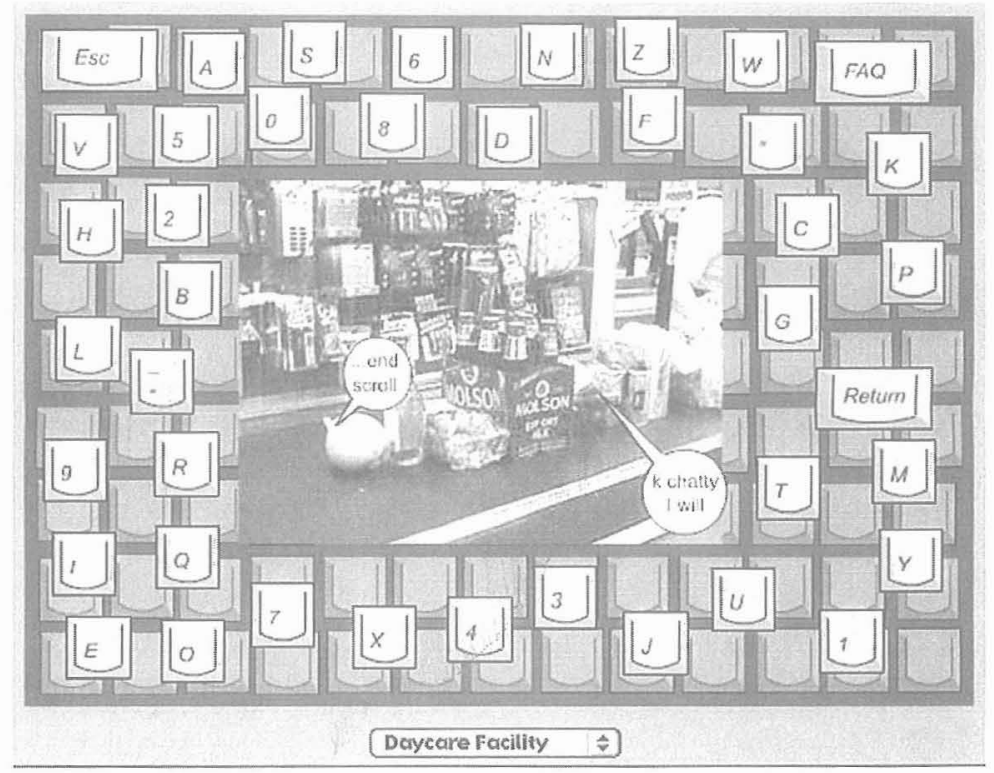

1998-99, commissioned by Dia Center for the Arts, www.diacenter.org/lucas 